\title{
PERSYARATAN PENDAFTARAN HAK PATEN UNTUK APLIKASI
}

\author{
Desi RatnaSari \\ 155100017 \\ Fakultas Komputer, 448757184 \\ Desiratnasari.student@umitra.ac.id
}

\begin{abstract}
Karya intelektual yang bersifat kreasi estetika seperti hak cipta dan desain industri lrelatif mudah memperoleh hak paten. Termasuk penemuan metode program komputer, presentasi mengenai informasi yang ditemukan lebih mudah memperoleh ijin paten. Meskipun demikian, ada pula karya intelektual yang ternyata tidak dapat dipatenkan. Berikut karya intelektual yang tidak dapat dipatenkan:

Apabila pihak lain yang memperoleh pengalihan hak dari inventor akan memiliki hak paten Selama 20 tahun dari hari pertama tanggal penerimaan. Sisanya, setelah 20 tahun hak ekslusif tersebut akan menjadi public domain. Public domain diperuntukan untuk masyarakat umum, tentu saja tetap melakukan proses ijin pada pemegang hak paten.

Hak paten dalam HaKI berprinsip territorial. Prinsip territorial dalam hal ini hak paten hanya berlaku di negara inventor mengajukan permohonan paten dan diberi. Pengajuan dilakukan dengan mengirimkan surat permohonan ke Direktoral Jenderal Hak Kekayaan Intelektual (DJHKI). Apabila inventor memperoleh hak paten di Indonesia, misalnya, maka hak paten yang diperoleh tidak berlaku atau tidak memiliki hak paten di negara lain.

Kewajiban inventor yang memperoleh hak paten HaKI berhak membayar biaya tahunan. Biaya tersebut bagian dari biaya pemeliharaan paten sampai dengan tahun terakhir masa perlindungan. Hak paten akan hilang secara hukum apabila tidak dibayar selama tiga tahun berturut-turut. Besar biaya pemeliharaan hak paten di tetapkan oleh PNBP Penerimaan Negara Bukan Pajak di Kementerian hukum dan HAM.
\end{abstract}

Kata Kunci : Kewajiban Invertor, PNBP dan HAM 


\section{A. INTRODUCTION}

Hak atas Kekayaan Intelektual (HaKI) penting untuk mengukuhkan penemuan para dosen. Salah satu perlindungan Hak atas Kekayaan Intelektual adalah mematenkan hasil penemuan. Di masyarakat umum mengartikan HaKI dan Paten dipahami sebagai istilah yang sama.

Paten salah satu bagian Hak atas Kekayaan Intelektual atau HaKI yang berfungsi untuk melindungi karya intelektual dosen, mahasiswa dan masyarakat umum yang menghasilkan karya. Karya intelektual bermacam-macam, mulai yang bersifat teknologi (invensi), penelitian, seni dan masih banyak lagi. Salah satu contoh karya intelektual invensi yang dapat dipatenkan dapat berupa produk dan proses. Misalnya penemuan alat untuk mengukur kadar $\mathrm{pH}$ dalam air untuk mengetahui kadar normal untuk tanaman.

\section{SYARAT KARYA INTELEKTUAL YANG DAPAT DIPATENKAN}

Kategori karya dan penemuan dapat dipatenkan berdasarkan karakteristik tertentu. Dengan kata lain, tidak semua hasil penemuan bisa dipatenkan. Karya/penemuan yang dapat di patenkan harus memenuhi syarat secara substantif. Secara substantif dibagi menjadi dua hal sebagai berikut.

\section{Bersifat Baru}

Hasil karya intelektual belum pernah dipublikasikan terlebih dahulu. Baik di publikasikan di media apapun. Adapun langkah yang harus segera di urus agar memperoleh hak paten, dengan mengajukan permohonan. Setelah mengajukan permohonan, akan memperoleh tanggal penerimaan. Jika karya intelektual dipublikasikan sebelum memperoleh tanggal penerimaan, maka permohonan bisa gagal.

\section{Bersifat Inventif}

Prinsip memperoleh paten HaKI bersifat inventif, atau kemampuan untuk menciptakan, merancang sesuatu yang sebelumnya belum pernah ada. Paten hanya diberikan pada karya intelektual hanya diberikan pada penemu yang memiliki person skilled in the art.

\section{Bersifat Aplikatif}

Maksud aplikatif hasil penelitian yang ditemukan dapat dilakukan secara berulang-ulang. Dapat juga diartikan memiliki tingkat kemanfaatan bagi masyarakat. Semakin hasil penemuannya digunakan masyarakat luas, mengindikasikan bahwa 
penemuannya berhasil sebagai solusi atas permasalahan yang muncul. Karya intelektual memiliki syarat konsisten, tidak mudah berubah-ubah.

Karya intelektual yang bersifat kreasi estetika seperti hak cipta dan desain industri lrelatif mudah memperoleh hak paten. Termasuk penemuan metode program komputer, presentasi mengenai informasi yang ditemukan lebih mudah memperoleh ijin paten. Meskipun demikian, ada pula karya intelektual yang ternyata tidak dapat dipatenkan. Berikut karya intelektual yang tidak dapat dipatenkan:

Karya intelektual tidak menentang peraturan Hak atas Kekayaan Intelektual. Diantarannya, tidak mengumumkan karya sebelum mengajukan surat permohonan. Hasil karya intelektual tidak bertentangan dengan peraturan undang-undangan yang berlaku. Hasil karya juga tidak menentang moralitas agama, mengandung RAS dan menganggu ketertiban umum.

Karya intelektual tidak dalam praktik coba-coba. Karya intelektual bukan termasuk metode-metode dan teori. Misalnya metode pemeriksaan, pengobatan, perawatan, pembedahan dan pengobatan. Termasuk teori dan rumus matematika. Sehebat apapun rumus menyelesaikan permasalahan, tetap tidak dapat dipatenkan.

\section{CATATAN MEMPEROLEH HAK PATEN}

Pemilik karya intelektual disebut dengan istilah inventor. Inventor bisa dilakukan secara individu maupun kelompok. Inventor lebih mudah mendapatkan hak paten atas hasil penemuan karya intelektual mereka. Sedangkan untuk diluar inventor terlebih dahulu memperoleh pengalihan hak secara tertulis dari sang inventor.

Apabila pihak lain yang memperoleh pengalihan hak dari inventor akan memiliki hak paten Selama 20 tahun dari hari pertama tanggal penerimaan. Sisanya, setelah 20 tahun hak ekslusif tersebut akan menjadi public domain. Public

domain diperuntukan untuk masyarakat umum, tentu saja tetap melakukan proses ijin pada pemegang hak paten.

Hak paten dalam HaKI berprinsip territorial. Prinsip territorial dalam hal ini hak paten hanya berlaku di negara inventor mengajukan permohonan paten dan diberi. Pengajuan dilakukan dengan mengirimkan surat permohonan ke Direktoral Jenderal Hak Kekayaan Intelektual (DJHKI). Apabila inventor memperoleh hak paten di Indonesia, misalnya, 
maka hak paten yang diperoleh tidak berlaku atau tidak memiliki hak paten di negara lain.

Kewajiban inventor yang memperoleh hak paten HaKI berhak membayar biaya tahunan. Biaya tersebut bagian dari biaya pemeliharaan paten sampai dengan tahun terakhir masa perlindungan. Hak paten akan hilang secara hukum apabila tidak dibayar selama tiga tahun berturut-turut. Besar biaya pemeliharaan hak paten di tetapkan oleh PNBP Penerimaan Negara Bukan Pajak di Kementerian hukum dan HAM.

Biaya pembiayaan terdiri dari biaya pokok dan biaya per klaim. Periode pembayaran setiap satu tahun sekali, berdasarkan tanggal yang sama dengan pemberian pengajuan paten pertama kali. Dengan kata lain, batas akhir pembayaran jatuh pada tanggal yang sama saat pengajuan.

HAK PATEN BERSIFAT TIMESENSITIVE

Hak paten diberikan pada inventor pertama kali yang mengajukan permohonan paten. Waktu pengajuan permohonan bersifat krusial dan bersifat time-sensitive. Dengan kata lain, apabila ada dua inventor yang memiliki karya intelektual yang sama persis, maka yang diakui adalah inventor yang lebih dulu mengajukan permohonan. Alaxander Graham
Bell dinobatkan sebagai penemu telepon karena selangkah lebih cepat mendaftarkan hak patennya daripada kompetitornya pada waktu itu.

Hak paten dalam HaKI bagi mereka yang sudah tahu, berbondong-bondong mengajukan permohonan. Biaya permohonan hak paten sebesar Rp. 750.000,00. Sekalipun mereka sebenarnya masih ragu untuk memastikannya. Menariknya, ada sebagian yang tidak mempedulikan biaya pendaftaran paten untuk karya intelektual yang tidak komersial. Mereka tetap tidak merasa rugi, karena memperoleh hak paten lebih penting dari sekedar keuntungan secara ekonomi. Mengingat, hak paten tidak dapat dipatenkan lagi apabila sudah dipublikasikan.

\section{PROSEDUR MENGAJUKAN PERMOHONAN HAK PATEN HAKI}

Syarat mengajukan permohonan hak paten HaKI karya intelektual benar-benar terbarukan. Belum ada yang pernah mengajukan sebelumnya. Adapun cara pengecekan apakah karya kita terbarukan atau tidak. kita dapat melakukan pengecekan dokumen paten di database DJHKI dan kantor paten di luar negeri. Misalnya, pengecekan terhadap jurnal ilmiah dan sejenisnya. 
Jika karya kita belum bersifat terbarukan, proses selanjutnya adalah membuat proposal pengajuan paten. Proposal pengajuan paten meliputi judul invensi, latar belakang invensi, deskripsi singkat karya intelektual yang ditemukan dan gambar teknik. Gambar teknik yang disertai dengan uraian singkat. Kemudian dilengkapi dengan abstrak dan klaim. Rangkaian inilah yang kemudian disebut dengan penyusunan spesifikasi paten.

Spesifikasi paten sebagai syarat minimum yang harus disertakan. Adapun tiga syarat yang harus dipenuhi untuk memperoleh filing date, diantarannya memenuhi Spesifikasi paten, formulir permohonan dan biaya pendaftaran. Adapun persyaratan lain sebagai formalitas, dimana syarat ini dapat dilengkapi selama tiga bulan setelah menerima tanggal penerimaan. Berikut syarat permohonan yang perlu dipersiapkan.

1. Surat pernyataan hak

2. Surat perngalihan hak

3. Surat kuasa

4. Fotocopi KTP/identigas pemohon

5. Fotokopi Akta pendirian badan hukum yang dilegaliris

6. Fotokopi NPWP badan hukum

7. Fotokopi KTP atas nama pemohon badan hukum untuk ditandatangai surat pernyataan dan surat kuasa.
Apabila syarat poin di atas sudah lengkap, inventor tinggal menunggu hasil dari DJHKI. Pengumuman akan dipublikasikan secara umum setelah 18 bulan dari hasil pengajuan. Pemohon paten selama menunggu pengumuman dimuat di berita resmi paten dan media resmi. Tujuannya untuk mengetahui hak kekayaan intelektual yang dipatenkan. Apabila masyarakat atau inventor luar merasa keberatan karena dianggap tidak memenuhi syarat untuk dipatenkan, dapat mengajukan secara tertulis kepada DJHKI.

Khusus inventor yang ditolak, diperbolehkan mengajukan banding ke Komisi Banding Paten. Nantinya, akan berlanjut ke Pengadilan Niaga dan kasasi Mahkamah Agung. Apabila inventor pengajuan hak paten tetap ditolak, maka hasil hak kekayaan intelektual akan menjadi public domain. Sedangkan untuk yang memperoleh hak paten, akan meperoleh sertifikat hak paten dari DJHKI.

Itulah ulasan tentang Hak Paten Hak atas Kekayaan Intelektual (HaKI). Mengingat syarat dan prosederu pengajuan paten $\mathrm{HaKI}$ cukup panjang, ada lembaga konsultan HaKI. Semoga ulasan ini bermanfaat. Selamat berkarya melahirkan karya intelektual. 


\section{B. CONCLUSION}

Syarat mengajukan permohonan hak paten HaKI karya intelektual benar-benar terbarukan. Belum ada yang pernah mengajukan sebelumnya. Adapun cara pengecekan apakah karya kita terbarukan atau tidak. kita dapat melakukan pengecekan dokumen paten di database DJHKI dan kantor paten di luar negeri. Misalnya, pengecekan terhadap jurnal ilmiah dan sejenisnya.

Jika karya kita belum bersifat terbarukan, proses selanjutnya adalah membuat proposal pengajuan paten. Proposal pengajuan paten meliputi judul invensi, latar belakang invensi, deskripsi singkat karya intelektual yang ditemukan dan gambar teknik. Gambar teknik yang disertai dengan uraian singkat. Kemudian dilengkapi dengan abstrak dan klaim. Rangkaian inilah yang kemudian disebut dengan penyusunan spesifikasi paten.

Spesifikasi paten sebagai syarat minimum yang harus disertakan. Adapun tiga syarat yang harus dipenuhi untuk memperoleh filing date, diantarannya memenuhi Spesifikasi paten, formulir permohonan dan biaya pendaftaran. Adapun persyaratan lain sebagai formalitas, dimana syarat ini dapat dilengkapi selama tiga bulan setelah menerima tanggal penerimaan. Berikut syarat permohonan yang perlu dipersiapkan.

8. Surat pernyataan hak

9. Surat perngalihan hak

10. Surat kuasa

11. Fotocopi KTP/identigas pemohon

12. Fotokopi Akta pendirian badan hukum yang dilegaliris

13. Fotokopi NPWP badan hukum

14. Fotokopi KTP atas nama pemohon badan hukum untuk ditandatangai surat pernyataan dan surat kuasa.

Apabila syarat poin di atas sudah lengkap, inventor tinggal menunggu hasil dari DJHKI. Pengumuman akan dipublikasikan secara umum setelah 18 bulan dari hasil pengajuan. Pemohon paten selama menunggu pengumuman dimuat di berita resmi paten dan media resmi. Tujuannya untuk mengetahui hak kekayaan intelektual yang dipatenkan. Apabila masyarakat atau inventor luar merasa keberatan karena dianggap tidak memenuhi syarat untuk dipatenkan, dapat mengajukan secara tertulis kepada DJHKI.

Khusus inventor yang ditolak, diperbolehkan mengajukan banding ke Komisi Banding Paten. Nantinya, akan berlanjut ke 


\section{Section Class Content}

\begin{abstract}
Pengadilan Niaga dan kasasi
Mahkamah Agung. Apabila inventor pengajuan hak paten tetap ditolak, maka hasil hak kekayaan intelektual akan menjadi public domain. Sedangkan untuk yang memperoleh hak paten, akan meperoleh sertifikat hak paten dari DJHKI.
\end{abstract}

Itulah ulasan tentang Hak Paten Hak atas Kekayaan Intelektual (HaKI). Mengingat syarat dan prosederu pengajuan paten $\mathrm{HaKI}$ cukup panjang, ada lembaga konsultan HaKI. Semoga ulasan ini bermanfaat. Selamat berkarya melahirkan karya intelektual.

\section{ACKNOWLEDGEMENT}

University Of Indonesia

University Of Mitra Indonesia

Telkom University

University Of Mellbourne

Saitama University 
Indonesia. Retrieved From Osf.Io/Pbrn9.

\section{REFERENCE(Based ISO 690 )}

A. S. Putra And O. M. Febriani, "Knowledge Management Online Application In Pdam Lampung Province," In Prosiding International Conference On Information Technology And Business (Icitb), 2018, Pp. 181-187.

[2] A. S. Putra, O. M. Febriani, And B. Bachry, "Implementasi Genetic Fuzzy System Untuk Mengidentifikasi Hasil Curian Kendaraan Bermotor Di Polda Lampung," J. Sist. Inf. Dan Manaj. Basis Data, Vol. 1, No. 1, Pp. 21-30, 2018.

[3] O. M. Febriani And A. S. Putra, "Sistem Informasi Monitoring Inventori Barang Pada Balai Riset Standardisasi Industri Bandar Lampung," J. Inform., Vol. 13, No. 1, Pp. 90-98, 2014.

[4] Putra, Arie Setya. "2018 Artikel Struktur Data, Audit Dan Jaringan Komputer." (2018).

[5] Putra, A. S. (2018, July 17). Paperplain Fundamental Create Application With Borland Delphi 7.0 University Of Mitra

\section{E. REFERENCE(Based APA)}

Putra, A. S., Aryanti, D. R., \& Hartati, I. (2018, November). Metode SAW (Simple Additive Weighting) sebagai Sistem Pendukung Keputusan Guru Berprestasi (Studi Kasus: SMK Global Surya). In Prosiding Seminar Nasional Darmajaya (Vol. 1, No. 1, pp. 85-97).

Sari, D. P., Febriani, O. M., \& Putra, A. S. (2018, November). Perancangan Sistem Informasi SDM Berprestasi pada SD Global Surya. In Prosiding Seminar Nasional Darmajaya (Vol. 1, No. 1, pp. 289-294).

Putra, A. S. (2018). Paperplain: Execution Fundamental Create Application With Borland Delphi 7.0 University Of Mitra Indonesia.

Putra, A. S., Sukri, H., \& Zuhri, K. Sistem Monitoring Realtime Jaringan Irigasi Desa (JIDES) Dengan Konsep Jaringan Sensor Nirkabel. IJEIS (Indonesian Journal of Electronics and Instrumentation Systems), 8(2), 221232.

Darmawan, A., Yuliawati, D., Marcella, O., \& Firmandala, R. (2016). Sistem Absensi dan Pelaporan 
Berbasis Fingerprint dan SMS Gateway. EXPLORE, 7(1).

Febriani, O. M., Wahyuni, T., \& Yusuf, S. (2017). DESIGN OF WEBSITE-BASED INFORMATION SYSTEM FOR EDOCUMENT ADMINISTRASI IN THE COMMUNITY SERVICE UNIT (A Case Study at Rajabasa District). INTERNATIONAL JOURNAL OF COMPUTERS \& TECHNOLOGY, 16(7), 7010-7020.

Febriani, O. M., \& Wahyuni, T. (2017, October). PERANCANGAN SISTEM E-DOCUMENT ADMINISTRASI LOGBOOK PENELITIAN PADA UNIT LAYANAN DI BANDAR LAMPUNG. In Prosiding Seminar Nasional Darmajaya (Vol. 1, No. 1, pp. 187-194).

Febriani, O. M., \& Permadi, A. B. (2017). Implementasi Sistem Aplikasi Data Bimbingan dan Pelanggaran Siswa pada Sekolah Menengah Atas di Lampung Tengah dengan Metode Analisis dan Desain Sistem Terdistribusi (SSAD). EXPERT, 7(1).

Febriani, O. M., \& Ambarwati, L. (2015). PERANCANGAN APLIKASI PENGOLAHAN DATA PENJUALAN UKM KELANTING KHAS TELO DESA SIDOHARJO KECAMATAN JATI AGUNG KABUPATEN LAMPUNG SELATAN. Jurnal Teknologi Informasi dan Bisnis Pengabdian Masyarakat Darmajaya, 1(1), 77-95.

Febriani, O. M. (2015). Rancang Bangun Aplikasi E- commercemenggunakan Freewebstore pada UKM Kelanting di Desa Sidoharjo Lampung Selatan. Prosiding Sembistek 2014, 1(02), 446-458. 